\title{
grown-upness or living philosophically?
}

\author{
claire cassidy ${ }^{1}$ \\ university of strathclyde, scotland
}

\section{abstract}

This article addresses a particular element of Gert Biesta's presentation to the International Council for Philosophical Inquiry with Children conference in Madrid, 2017: the notion of grown-upness and how this might be problematic in practising Philosophy with Children. Biesta's grown-upness seems to imply a deficit view of children, despite his suggestion that the concept is not a developmental one. It is proposed here that the idea of grown-upness demands that children are positioned by others - adult others which further denies their agency and fails to allow that they may be active in the world they inhabit. Biesta's suggestion that grown-upness is about 'a way of being in the world' is discussed in relation to how Philosophy with Children positively encourages participants to engage with others by attending to a range of views and perspectives without situating themselves at the centre. What is proposed is that the very practice of Philosophy with Children enables participants to engage with questions of interest to themselves and others in a community of philosophical inquiry. Community is seen as crucial in supporting individuals to recognize the world and those other than themselves in living and thinking together. This, it is suggested, is about living philosophically rather than being 'grown-up'. The article concludes that emphasis on the philosophical element of the practice rather than on the children who engage in it may address the deficit view of children/child thrown-up by Biesta. In considering the 'age of instrumentalism', as Biesta calls it, and how Philosophy with Children might tackle this, it may be more helpful to talk about practical philosophy or community of philosophical inquiry, where child/adult status is not the focus.

keywords: philosophy with children; child; grown-upness; practical philosophy; community of philosophical inquiry;

\section{crescimento ou viver filosoficamente?}

resumo

Este artigo trata de um elemento particular da apresentação de Gert Biesta na Conferência da International Council for Philosophical Inquiry with Children, em Madri, em 2017: a noção de "crescimento" e como ela pode ser problemática na prática da Filosofia com Crianças. O "crescimento" de Biesta parece implicar uma visão deficitária das crianças, apesar de sua sugestão de que o conceito não se trata de um conceito de desenvolvimento. É proposto aqui que a ideia de "crescimento" exige que as crianças sejam posicionadas por outros - adultos - que acabam por negar a sua agência e falham em permitir que elas possam ser ativas no mundo que habitam. A sugestão de Biesta, de que o "crescimento" é sobre "um modo de se estar no mundo" é discutida em relação a como a Filosofia para Crianças encoraja positivamente os participantes a engajar-se em questões de interesse deles mesmos e dos outros, em uma comunidade de investigação filosófica. A comunidade é vista como crucial no apoio aos indivíduos em reconhecer o mundo e os outros a viver e pensar melhor. É sugerido que isto é uma questão de viver

\footnotetext{
${ }^{1}$ E-mail: claire.cassidy@strath.ac.uk
} 
filosoficamente em vez de ser "crescido" ("grown-up"). O artigo conclui que a ênfase no elemento filosófico da prática ao invés de na criança que a exerce pode falar da visão deficitária de crianças/criança que é projetada por Biesta. Considerando a "era da instrumentalização", como Biesta a chama, e como a filosofia para crianças deve enfrentála, talvez seja mais eficaz falarmos sobre filosofia prática ou comunidade de investigação filosófica, onde o status criança/adulto não está no foco.

palavras-chave: filosofia para crianças; criança; "crescimento"; filosofia prática; comunidade de investigação filosófica.

\section{¿crecimiento o vivir filosóficamente?}

resumen

Este artículo aborda un elemento particular de la presentación de Gert Biesta en el Congreso del ICPIC en Madrid, 2017: la noción de crecimiento y cómo ella podría ser problemática en la práctica de la Filosofía con los Niños. La idea de crecimiento de Biesta parece implicar una visión deficitaria de los niños, a pesar de su sugerencia de que el concepto no es supone una concepción evolutiva. Aquí se propone que la idea de madurez exige que los niños sean posicionados por otros - otros, adultos - que además niega su agencia y no permite que puedan ser activos en el mundo que habitan. La sugerencia de Biesta de que el crecimiento es una "forma de ser en el mundo" se discute en relación a cómo la Filosofía con Niños anima positivamente a los participantes a participar con otros asistiendo a una gama de puntos de vista y perspectivas sin situarse en el centro. Lo que se propone es que la misma práctica de Filosofía con Niños permite a los participantes dedicarse a cuestiones de interés para ellos y para otros en una comunidad de investigación filosófica. La comunidad es vista como crucial para apoyar a los individuos a reconocer al mundo y a aquellos que no son ellos mismos para vivir y pensar juntos. Esto, se sugiere, tiene más que ver con vivir filosóficamente que con ser "crecido". El artículo concluye que el énfasis en el elemento filosófico de la práctica más que en los niños que participan de ella puede dar voz a la visión deficitaria de los niños expresada por Biesta. Al considerar la "edad del instrumentalismo", como la llama Biesta, y cómo Filosofía con niños puede abordarla, puede ser más útil hablar de filosofía práctica o comunidad de investigación filosófica, donde el estatus de niño / adulto no es el foco.

palabras clave: filosofía con niños; niño; crecimiento; filosofía práctica; comunidad de investigación filosófica. 
grown-upness or living philosophically?

Grown-upness; a word used by Biesta to describe the manner of being in which we ought to exist in the world. Grown-upness is not, according to Biesta, about a developmental trajectory so beloved by developmental psychologists. In this he is, arguably, in error. Grown-upness is directional, particularly in its use of the word 'up'; by definition, it demands some kind of trajectory since nothing is born or begotten grown-up. Grown-upness is a noun that explains a particular state, deriving from the term, grown-up, and the associated verb to grow up. In order to be considered grown-up something has to grow up and subsequently it might attain grown-upness. We cannot simply 'reclaim' grown-upness, as Biesta suggests, because a process must be gone through in order to acquire such status as being grown-up. That process is necessarily developmental in one way or another and it is the goal to which the growing thing aims. It is unhelpful of Biesta to acknowledge that his use of the word grown-upness is atypical; it is somewhat removed from the common understanding or usage of being grown-up that it means the word cannot, as he recommends, be reclaimed. Biesta, instead, in using it in this fashion, seems to be appropriating the term rather than reclaiming it, since the context - Education - from which he chooses to reclaim it, would not employ it in the alternative manner presented by Biesta. He needs to acknowledge all that is bound-up with such a notion. The aspiration to grown-upness leads to another issue with Biesta, that children ought to aspire to grown-upness, an end point implied by Biesta's use of the term.

When talking about children and being grown-up or exhibiting grownupness, it presumes that the end point is desirable. The end point for children is, inevitably, adulthood. While Biesta, in his lecture, professes that grown-upness was available to children as well as to adults, he continues to speak within the child/adult binary that ensures the grown-up adult is the destination to be arrived at. It is worth acknowledging that not all adults, conventionally referred to as 'grown-ups', act in accord with what Biesta might assert are the qualities required 
of grown-upness. That aside, however, the view of the child as deficit in some way, has predominated in common discourse and educational thinking, and the proposition that grown-upness as 'the existential challenge where ego is not put at the centre' as the aim of education reconfirms this. Indeed, the power to name individuals or groups as grown-up or of demonstrating grown-upness is retained by adults. Even were children to be considered grown-up, it would not likely be that they would ascribe themselves with such an appellation. Much has been written about the place of children in society and that they are often not seen as full members of that society (FRIQUENON, 1997; MAYALL, 2007; CASSIDY, 2007; QVORTRUP, 2006, 2007). Indeed, children often collude with this view in their descriptions of the society in which they live (CONRAD, CASSIDY \& MATHIS, 2015), seeing themselves as set apart, as devoid of the power ascribed to adults. This is because children tend to be seen as deficient in the ways and means of being. They are irrational, impetuous, illogical, emotional, uncontrolled and are unable to reason, articulate and think well. They are, also, ego-centric. This is in direct opposition to those who are adults, or are grown-up. Adults - grown-ups are competent; they can reason, argue, control themselves and their emotions and are reasonable. They are, also, able to avoid ego-centrism. The child is often described in negative terms, in ways that are used to illustrate how they lack the capacities and capabilities of their adult counterparts (CASSIDY, 2007). Thus, childhood is the time when growing-up takes place.

\section{becoming grown-up}

Stables (2008) outlines three ways of defining the child. The first is that we are all children, having all been born of parents. The second is that we might define it by age such as in the United Nations Convention on the Rights of the Child (UNITED NATIONS, 1989), under Article 1, where children are considered to be under eighteen years-old, unless majority in their country is attained earlier. Leaving aside the many problems with the UNCRC definition, Stables offers a third: the child as becoming. This third definition is the dominant view of the child, one that sees childhood as 'a period of constrained preparation' (STABLES, 
2008, p.4), where the child is socialised and trained into the kind of individual the particular society in which she lives sees fit (SHAMGAR-HANDELMAN, 1994). The being to which the child strives is always there within her. The unfinished child, as such the becoming child must be, has potential to which she is directed. She will always become an adult in the same way that an acorn will become an oak tree or a foal a horse; the child is destined to grow-up, under such a view, to become an adult. Kennedy (1992, 2006), in exploring child as becoming, also suggests that the child is considered to be raw material, that the adult is always travelling with the child until the potential is reached; that potential, is adulthood. On reaching adulthood one is grown-up. Part of the problem in proposing that grown-upness is a desirable state for individuals to attain is that the individuals who determine this view are, invariably, adults; adults determine who has power and how it is employed. So, while Biesta makes clear that under his definition of grown-upness that both adults and children can be grown-up, he fails to acknowledge that it is adults who hold the power to do the naming. Further, it is adults who present Biesta's 'existential challenge' of 'being in the world where we don't put our ego in the centre'. This notion perpetuates the idea that those who have not acquired grown-upness - children - position their egos at the centre of their being. This is recognised by the likes of Cook (2015) who asserts that 'Children can never simply stand for themselves as individuals in the here and now... they wear upon their bodies and dispositions their social worlds' (p.4) and these social worlds are determined by adults, and this, it seems, includes whether or not they exhibit grown-upness.

\section{children as subjects}

In acknowledging that adults retain the power in society Qvortup (2006) urges that we ought to exercise caution that adulthood is not seen as 'more significant than childhood' (QVORTUP, 2006, p. 435). This is difficult if we are to accept Biesta's exhortation to 'exist in the world as subject'. Subject has a range of meanings, however, but if we are to see the child as subject of the world, then it sets her apart. If the world is seen as the local society of which one is a part, then 
this is governed by adults, so the child becomes subject of the adult world, or subjected to the adult world. If, however, the world is greater than the local, and more than the adult sum of that world, then the child as subject of that world may be further empowered. In so saying, though, a subject owes a certain allegiance to the realm in which she belongs and is governed by that world. Perhaps the child is no different from the adult under such an understanding since there ought to be care for the world in which and with which one lives. The truly global takes precedence over the individual and positions the ego further away from the centre of one's being. This would be fine were it not for the fact that, as noted previously, the child is not afforded much autonomy or status in the decision-making element of being in the world. The notion of existing in the world as subject is not unproblematic. Biesta wonders how the world of Philosophy with Children (PwC) positions children in the world. In 'positioning' children, he again situates children in a context that fails to recognise them as agentic or autonomous. They do not position themselves but are, rather, situated by some other - usually an adult other.

\section{the ' $i$ ' in philosophy with children}

In his lecture, Biesta speaks about a robotic vacuum cleaner, 'an intelligent, adaptive system', as he calls it. He sees a problem, that the intelligent, adaptive system, while able to adjust and adapt to its environment, is not able to ask of the environment in which it is put if it is an environment worth adapting to. The vacuum cleaner is programmed; it works to survive rather than to live and it sees objects in its path as obstacles to be overcome. He is correct that we do not want children to be seen as robotic vacuum cleaners, and there is much in what is done in the name of schooling that perpetuates such a view. Biesta talks about the dangers of twenty-first century skills and how these, like the vacuum cleaner's 'skills', are focused on survival rather than living, a notion much richer in scope than the former would imply. The intelligent, adaptive system sees only the other as a hurdle to be countered; people - children and adults - have the capacity to recognise the other as someone or something to be encountered. While they may 
recognise obstacles, it is an important element of one's being that one welcomes encounters with the world and those who inhabit it. Indeed, Biesta speaks in his lecture of Levinas' idea of the self being awakened by the other. He also talks about resistance and the need to stay in the middle-ground where we destroy neither the world nor ourselves. It is an awakening of self that is possible when one seeks encounters with others and that some of these encounters demand that one encounters resistance to one's thoughts, ideas and ways of being. While the automatic vacuum cleaner may be adaptive to its environment, this is not desirable for those of us living in the world.

To live, rather than to survive, in the world one has the facility to move beyond the adaptive; one can shape and determine the environment. In order to do so, one must engage with the world and the others within it. One must encounter others and face resistance. At the same time, one must also offer resistance. If resistance is not addressed or offered we have, as one member of Biesta's audience proposed, a 'compromised child'. Biesta sees compromise in positive terms, where it situates the individual in the middle-ground and where one's desires are not suppressed but are given a 'reality check'. The danger is that the compromised child is a child that perpetuates the status quo, that she maintains her place in opposition to the 'grown-up' adult and that she does not have opportunities to question, to challenge, to encounter and to wonder 'if the desires she has are the desires she ought to have', as Biesta suggests. Indeed, the compromised child, the child who remains situated as a non-grown-up will not be inclined to address the distinction between surviving and living, she will be too busy adapting to their environment. The ' $\mathrm{I}$ ' of the compromised child is suppressed rather than there being a repositioning of the self in relation to others in order to advance living well.

\section{living philosophically}

One approach to resistance and to a 'sustainable life', as Biesta calls it, is through dialogue. Biesta raises the issue of Philosophy with Children (PwC) being too 'in the head', but through dialogue with others this need not be the case. By 
necessity PwC demands an encounter with others where, through structured dialogue, participants face resistance to their ideas and offer resistance to others. This does not mean that individual participants stick trenchantly to their positions, the activity demands listening and consideration of what is articulated. Socrates tells us that 'this even happens to be the greatest good for a human being - to construct arguments every day about virtue and the other things about which you hear me conversing and examining both myself and others' (Apology, 38a). Conversing, dialogue, is central to this way of living, of being in the world and, arguably, to being; as Sharp (1987) suggests, 'It is through speaking to other persons that one becomes a person oneself' (SHARP, 1987, p. 40).

$\mathrm{PwC}$ is different from formal, academic philosophy, the philosophy taught and studied in universities. In PwC participants engage in a structured dialogue with others about their ideas (GAZZARD, 1996; MURRIS, 2000). Derived from Dewey, the idea of shared meaning-making is a key element of PwC (LIPMAN, 2003). The notion of community is significant. Indeed, in the literature relating to PwC terms such as community of inquiry, community of philosophical inquiry and philosophical community of inquiry are common (see, for example: LIPMAN, 2003; PARDALES \& GIROD, 2006; MCCALL, 2009; MILLETT \& TAPPER, 2011). Community is more than a group of individuals; it requires independence and cooperation (CASSIDY, 2007). This is important in addressing Biesta's requirement that the ' $\mathrm{I}$ ' or ego is not put at the centre of our being in and of the world. While the self may be awakened through dialogue with others, the individual in the dialogic community is diminished, at least during the dialogue. Bearing in mind that whichever approach taken to $\mathrm{PwC}$ - and there are several - they are practices, undertaken over time. Over the course of participation, the dialogue itself becomes more important to the participants than the presentation of their own particular perspectives or the need to preserve those perspectives without movement or flexibility (SHARP, 1987; MCCALL, 2009). Participants raise questions that are of interest to themselves and the community and they engage with one another to reach understanding, though not necessarily agreement, about 
the questions addressed (CASSIDY, 2016). Their loyalty is to the shared search for meaning rather than to the pursuit of their own argument at the expense of others' arguments. The ego, in $\mathrm{PwC}$, is not at the centre; the community and the dialogue take precedence. This, of course, is not to say that the individual as individual is not important. Should the focus remain on only the community then the accusation that $\mathrm{PwC}$ is too much 'in the head' might be justified. It is hoped that engagement in philosophical dialogue will have a bearing on how one engages in and with the world (LIPMAN, 2003; MILLETT \& TAPPER, 2011), on one's being in the world.

Thinking together and reflecting on one's thinking is necessary if there is to be any impact on one's way of living rather than one's survival. Gazzard (1996) notes that philosophically reflective thinking should resonate and articulate with one's life and way of being; it should not be a discrete activity. This is echoed by the likes of Schertz (2007) who proposes that in engaging with philosophical dialogue, the affective domain is as enhanced as the cognitive and that passive empathy' is avoided. He takes this further to suggest that in teaching children to be empathetic the teacher is not reinforcing the social order; he sees it as 'a form of social liberation for the express purpose of sharing feeling states to foster personal and societal growth and transformation' (SCHERTZ, 2007, p.187) and that empathy is a 'psychological phenomenon that provides a connective link for moral action' (SCHERTZ, 2007, p.190). The need for moral action, under Biesta's view of being in the world, would appear to be vital if the ego is to be removed from the centre. Like Schertz (2007), Cassidy (2016) recognises the potential link between PwC, reflective thinking, and the lived experience when she states that 'The cognitive cannot and should not be separated from one's actions, regardless of one's place in society' (CASSIDY, 2016, p. 513). In this she acknowledges the place of children as members of society, as participants in the world who act in that world. She goes on to propose a deliberative society for all, that requires the checking and rechecking of ideas. The dialogic space needed for such a society is not limited to those who are 'grown-up'; philosophical encounters such as those 
proposed should be open to all. In so saying, Cassidy agrees with Veugelers (2007) that citizens are needed 'that are socially aware and autonomous [and that]... Democracy must be won repeatedly and maintained' (VEUGELERS, 2007, p. 110).

\section{conclusion}

It is children's status, voice, participation and rights that Biesta needs to consider further if he is to advocate that the ego be removed from the centre, that grown-upness, to use his definition, is attainable by all. His existential strategy can only fail to succeed in recovering children and their associated childhood if issues pertaining to their status in the world remain unaddressed. Without due consideration of these issues, children will always be seen as deficient, in a state of becoming, being positioned by adults and who are then not permitted to engage in advancing the world in which they live. There is not space here to explore the links between $\mathrm{PwC}$, rights and education for citizenship, but this may be where, as Cassidy (2016) proposes, the answer lies in advancing the notion of deliberative participation, where children may be inducted into living in the world in a way that does not put ego at the centre. Sharp (1987), too, proposes that children should have the opportunity to participate in dialogue, in a community of inquiry, from the earliest age, a community that situates its participants as 'a community of persons-in-relation' (SHARP, 1987, p.42). This is not to position children as deficient, though they may be less practised in their deliberations and will have had fewer opportunities to engage with the world of which they are a part than older members of society. Perhaps in speaking about Philosophy with Children a problem is presented that continues to see children, despite empirical evidence to the contrary (see, for example: GARCÍA MORIYÓN, REBOLLO \& COLOM, 2005; DANIEL, 2008; CASSIDY \& CHRISTIE, 2014; GORARD, SIDDIQUI \& HUAT SEE, 2015), as less than adept in their thinking, their reasoning and their will to engage with others and the wider world. In continuing to speak of Philosophy with Children, emphasis is placed on the condition and status of children. The focus of the practice itself ought to be on the philosophical. Perhaps this may be achieved if the movement that engages children in philosophical dialogue would consider a 
shift to describing what they do as practical philosophy, philosophical inquiry or a community of philosophical inquiry rather than Philosophy with Children. This, it is proposed, would allow a move away from suggestions of grown-upness as being the desired way of being, towards a way of being in the world that is deliberative and that does not see deliberation and its associated action as the preserve of any one group in that world, notably adults.

\section{references}

CASSIDY, C. Thinking Children. London: Continuum, 2007.

CASSIDY, C. Promoting human rights through Philosophy with Children. International Journal of Children's Rights 24(3), 499-521, 2016.

CASSIDY, C.; Christie, D. Community of Philosophical Inquiry: citizenship in the classroom. Childhood \& Philosophy 10(19), 33-54, 2014.

CONRAD, S-J.; CASSIDY, C.; MATHIS; C. Encouraging and supporting children's voices. In: TREMMEL, J.; Mason, A.; Dimitrijoski, I; Godli, P. (eds). Youth Quotas and Other Efficient Forms of Youth Participation in Ageing Democracies. Cham: Springer, 2015. COOK, D.T. (2015). A politics of becoming. When 'child' is not enough. Childhood 22(1), 3-5.

DANIEL, M-F. Learning to philosophize: positive impacts and conditions for implementation a synthesis of 10 years of research (1995 - 2005). Thinking 18(4), 3648, 2008.

FRIQUENON, M-L. What is a child? Thinking: the Journal of Philosophy for Children 13(1), 12-16, 1997.

GARCÍA MORIYÓN, F.; REBOLLO, I.; COLOM, R. Evaluating Philosophy for Children: a meta-analysis. Thinking: The Journal of Philosophy for Children 17(4): 14-22, 2005.

GAZZARD, A. Philosophy for Children and the discipline of philosophy. Thinking: the Journal of Philosophy for Children 12(4), 9-16., 1996.

GORARD, S.; SIDDIQUI, N.; HUAT SEE, B. (2015). Philosophy with Children: Evaluation Report and Executive Summary. London: Education Endowment Fund, 2015.

KENNEDY , D. The hermeneutics of childhood. Philosophy Today (Spring Issue), 44-58, 1992.

KENNEDY, D. The Well of Being. Childhood, Subjectivity, and Education. Albany: SUNY Press, 2006.

LIPMAN, M. Thinking in Education (2 ${ }^{\text {nd }}$ edition). Cambridge, Mass.: Cambridge University Press, 2003.

MCCALL, C. Transforming Thinking. Philosophical Inquiry in the Primary and Secondary Classroom. London: Routledge, 2009.

MAYALL, B. The sociology of childhood in relation to children's rights. International Journal of Children's Rights 8(3), 243-259, 2007.

MILLETT, S. and Tapper, A. Benefits of collaborative philosophical inquiry in schools. Educational Philosophy and Theory 44(5), 546-567, 2011.

MURRIS, K. Can children do philosophy? Journal of Philosophy of Education 34(2), 261-279, 2000. 
grown-upness or living philosophically?

PARDALES, M. J.; Girod, M. Community of inquiry: its past and present future. Educational Philosophy and Theory 38(3), 299-309, 2006.

QVORTRUP, J. Editorial: are children subjects or a liability? Childhood 13(4): 435-439, 2006. QVORTRUP, J. Editorial: a reminder. Childhood 14(4): 395-400, 2007.

SHAMGAR-HANDELMAN, L. To whom does childhood belong? In: QVORTRUP, J; BARDY, M.; SGRITTA, G.; WINTERSBERGER, H. (eds), Childhood Matters; Social Theory, Practice and Politics. Aldershot: Avebury, 1994.

SHARP, A.M. What is a 'Community of Inquiry'? Journal of Moral Education 16(1), 37-45, 1987.

SCHERTZ, M. Avoiding 'passive empathy' with Philosophy for Children. Journal of Moral Education 36(2), 185-198, 2007.

STABLES, A. Childhood and the Philosophy of Education. An Anti-Aristotelian Perspective London: Continuum, 2008.

UNITED NATIONS. United Nations Convention on the Rights of the Child. Geneva: United Nations, 1989.

VEUGELERS, W. Creating critical-democratic citizenship education: empowering humanity and democracy in Dutch education. Compare: A Journal of Comparative and International Education 37(1), 105-119, 2007.

received in: 14.08 .2017

accepted in: 26.08.2017 